European journal of American studies

Special Issue: Sound and Vision: Intermediality and American Music

\title{
Jazz Between the Lines: Sound Notation, Dances, and Stereotypes in Hergé's Early Tintin Comics
}

Lukas Etter

\section{OpenEdition}

\section{Journals}

Electronic version

URL: https://journals.openedition.org/ejas/12402

DOI: $10.4000 /$ ejas. 12402

ISSN: 1991-9336

Publisher

European Association for American Studies

Electronic reference

Lukas Etter, "Jazz Between the Lines: Sound Notation, Dances, and Stereotypes in Hergé's Early Tintin Comics ", European journal of American studies [Online], 12-4 | 2017, Online since 28 December 2017, connection on 08 July 2021. URL: http://journals.openedition.org/ejas/12402 ; DOI: https://doi.org/ 10.4000/ejas. 12402

This text was automatically generated on 8 July 2021 .

Creative Commons License 


\title{
Jazz Between the Lines: Sound Notation, Dances, and Stereotypes in Hergé's Early Tintin Comics ${ }^{1}$
}

\author{
Lukas Etter
}

1 Comics'-or, more broadly, graphic narratives'-relationship with jazz has been longstanding and complex. Artists and critics frequently use musical metaphors, particularly those related to improvisation, in their analyses of specific comics pages. As early as 1924, Gilbert Seldes drew a connection between jazz and comics in his assessment of what he termed the modern "lively arts," and Art Spiegelman and Philipp Johnston recently teamed up to revisit this connection in their comics-and-jazz projection performance titled Wordless! (2014; see also Bremgartner). Historical jazz scenes, such as that of Berlin nightlife in the 1930s or New York in the 1950s form an important thematic pool for contemporary graphic narratives (e.g., Lutes, Parisi; cf. Glaude, Stein).

2 Yet even when such thematically explicit references to jazz-such instances of "nested reception" (Newark)-are absent, we may find implicit allusions to jazz, and earlier musical and dancing styles that later came to be subsumed under this umbrella term. If an intermedial approach to cultural artifacts is best carried out by highlighting specificities not only of their medial but also their historical context (Rippl 2), it should be rewarding to examine pre-1945 Western European comics in terms of their notation of music and sound, as well as their depiction of musical performance and dance. I will zoom in on Hergé's early comics, particularly examples from the Tintin series, as a historically specific expansion of the visual dimension (text-image connections) into a musical one. While having been called the "most studied comic book series globally" (Beaty/Woo 18n2), its relationship to the "jazz age" seems understudied thus far. The present essay cannot single-handedly change this; rather, it consists of a series of closereadings, framed in discourses on (racialized) jazz historiography and details of Hergé's biography (as well as their auteurist mediatizations) - to be understood as an invitation for further studies on the topic. 


\section{Racial Politics and "Art Nègre" Discourse in 1920s Europe}

3 By the mid-1920s, American society was, in Gilbert Seldes' terms, "full in the jazz age" (qtd. in Kammen 96). European cities, including those in Belgium, were soon following suit (Danval 54-60, 116-121). During this period, in Brussels, Hergé started experimenting with a prototype hero ("Totor") and eventually sent his newly created Tintin on his first adventure (1929-1930, Tintin au pays des Soviets). Hergé's comics significantly shaped the tradition of Franco-Belgian comics storytelling. Interestingly, there are almost no explicit references to North American comics, ${ }^{2}$ and the same is true for jazz in the early Tintin albums. At the same time, most biographers note at least in passing that Hergé was fond of listening to jazz when drawing for Le Boy-Scout belge and later creating other illustrations and comics (cf. Mouchart/Rivière 34; Peeters, Son 304; Sterckx/Soupart 37). Sterckx contends that Hergé considered early jazz as a "noise" and a "force" at the same time (Sterckx, Médias 25-26). ${ }^{3}$ Most of this took place decades before Hergé's interest in jazzy forms of pop and progressive rock as of the 1960s.

4 Hergé once famously claimed that his influences had come from the visual arts more so than from music, and that he had never received any formal education in the latter (Sadoul); but even so, the popular craze for cakewalk, Charleston, and swing on the dancefloors of the period did not escape him. The same holds true for jazz's origins in and associations with African American culture(s), as a simple drawing (dated 1922) from one of his early sketchbooks illustrates (Goddin I.10): a group of three presumably African American musicians are playing wind instruments and percussion on stage while laughing and moving their limbs in an almost jumping-jack fashion. The drawing recalls the widely distributed vaudeville-inspired depictions of early jazz performances, problematized for their racializing or racist implications only much later (cf. also Blake 66; Higginson 11-13). ${ }^{4}$

5 A detailed discussion of white Western European intellectuals' and artists' reactions to, and involvement in, the interwar jazz cultures is beyond the scope of this article. ${ }^{5}$ In her study Le Tumulte Noir, Jody Blake has retraced the nexus between African American music and the several groups of white visual artists who drew on white ethnographers' material from the African continent for their inspiration (Picasso's and Matisse's "primitivism," French futurist artists, the Parisian Dada events, and so on). Blake's main focus is on France, yet several of the major threads of her argument extend into other parts of Western Europe-including Hergé's native Belgium, particularly in regards to the art periods after Picasso and Matisse. The Western European public of the 1920s was steeped in visual popular culture of exploration and travelling the world, and ethnography had just established itself in the colonialist and exoticist view of the time. Yet the principal focus for many French-language intellectuals in their perceptions of things "African" were the forms of rhythm, music, and dance that started to become common features of both exhibitions and music-halls in Paris (cf. Blake).

6 At least in the 1910s and early 1920s, African American musicians in France and Western Europe were predominantly catering to white audiences, de facto resulting in a restriction of what types of music were played (Tucker 320-324). As Blake notes, there were exceptions. Among them figured several Paris-based clubs where African 
Americans played improvised instrumental music after the end of the official setreportedly for their own pleasure and beyond commercial constraints. Langston Hughes, who financed parts of his stay in Paris by working in one of these clubs, observed and described them retrospectively as jam sessions avant la lettre (Blake 114115). According to José André Lacour's memories, Brussels' early jazz club Le Bœuf sur le Toit received its name less from an eponymous Paris-based club than from the fact that "bœuf," the French word for ox, was a slang term for this kind of open-ended improvisation (cf. Lacour 37).

7 Several French and Belgian surrealists frequented these scenes and wrote enthusiastic accounts, seeing immediate links between the concepts of automatism and improvisation. As present-day scholars point out, these writings are in large parts steeped in exoticist perspectives and racial essentialisms, and many of the friendships with African Americans some surrealists would later write about can be assumed to have been asymmetrical (cf. Blake 185n88; see also Lane 35-64; Higginson 37-43). Although highly problematic from this angle, the surrealists' embrace of the jazz of the années folles-the 1920s in Paris and beyond-also crucially coincided, for many, with their decidedly anti-colonialist and anti-imperialist political convictions, as Blake notes.

8 Such anti-colonialist sentiments were not exactly the politics of Hergé's environment, as is well known. The conservative reaction to what was subsumed under the expression art nègre (referring to cultural productions by Africans, African Americans, and other hyphenated blacks) and the jazz tunes closely linked to it at the time were often harsh in Western Europe. Rallying against what they saw as decadence, the Catholic church and nationalist organizations had started their calls to return to 'decency' especially as of 1925 (Blake 1-9; Higginson 41-43). ${ }^{6}$

9 Racist caricatures of black people were a frequent means of expression of this viewpoint. It is in this context that we have to read the earliest substantial notation of music in the Tintin series, namely, a panel from the first version of Tintin au Congo, a narrative serialized between May 1930 and June 1931. ${ }^{7}$ To say that this version was set in black and white may sound like a mediocre pun: Even more so than its (only slightly toned down) later full color version, the early Congo adventure has rightly been accused for its depiction of the "Congolese," who speak in infinitives and behave childlike and naïvely for the most part. This colonialist stance would resurface occasionally in later albums-less so with Tintin's blackface used as a disguise in L'Oreille cassée, but prominently at other places, e.g., Tintin's explicit wish to talk to the "whites" in the jungle of Les Cigares du pharaon-before racism and Othering is directly addressed in the last albums. ${ }^{8}$ Yet never again have they acquired as direct and prominent a role as in this early Tintin au Congo album.

10 Link 1 [image to the left]: http://www.moliba-makasi.fr/olele-olele.php

11 And never again has a Tintin album addressed musical notation in a more intermedially explicit manner than in this panel, taken from the 34th planche (page) of Tintin's Congo adventures (Link 1). In a landscape-oriented rectangular panel, the white priest offers to show Tintin and Milou their "mission"; they are being rowed there in a canoe by six black Congolese young men with stereotypically broad, minstrel-like lips, who sing a Congolese folk song. The song, "U-élé! U-élé! U-élé! Ma-li-ba! Ma-ka-si!," circumscribed by Costantini as "Oélé [i.e., a specific river in the Congo basin], the current is very 
strong," is reportedly a song in Lingala frequently sung by European boy scouts. ${ }^{9}$ If we include Milou, whose renaming as "Missié" is part of the Congolese' supposedly funny obsequiousness in this album (Hergé, Congo 6.1), the highly detailed partition of the song placed in the singing canoeists' speech bubble is mirrored in the choice of stereotyped characters depicted: Three half notes, whose long duration mimics the three white figures in power, and six pairs of "black" notes (almost exclusively eighth notes), for the six pairs of arms who do the physical work necessary for transporting the whites, in addition to singing. Hergé's panel interpictorially revisits a nineteenthcentury canoe-with-notes caricature drawn by Eugène Burnand, too. Though there are no "white" figures in the canoe, Burnand's drawing (Punch, July 1878) was published as an illustration of a starkly colonialist short story, a story that prominently satirized the contrasting skin colors of its protagonists (Link 2; see also Bachmann 243, 249). ${ }^{10}$

Link 2 [central image]:

http://digi.ub.uni-heidelberg.de/diglit/punch1878a/0028

Whether it is because this "joke" on the black-and-white contrasts was too controversial even for Hergé and his team, or whether the reasons lay elsewhere: When the black-and-white version was abandoned in favor of a colored one (1946) and some of the immediate allusions to the Belgian colonial contexts were eradicated (while "petit-nègre" talk stayed on), the panel in question was replaced. The new one (35.7; Link 3) occupied more space on the page and depicted an astoundingly detailed setting in terms of plants in the back- and foreground. The altered number of charactersMilou is not visible; the rowers are reduced to five, one of whom playing the drum-has the numerology disappear. The precisely noted partition in the speech bubble is gone; the three pairs of eighth notes seem randomly interspersed between the lyrics, with no evident connection between the two. Burnand's example, conceptually connected to the old panel and iconographically to the new one, can formally serve as the missing (aesthetic) link.

Link 3 [image to the right]:

http://www.moliba-makasi.fr/olele-olele.php

Apart from the black-and-white Congo panel, there are hardly any Tintin albums that contain a musical score that is concretely referential. An exception is found in La Castafiore's first two appearances-an example indeed which comes without an evident baggage of racial stereotyping (although gender stereotypes abound). In a black-andwhite panel from Le Sceptre d'Ottokar, published in January 1939, opera singer Bianca Castafiore sings her famous "Air des bijoux" with two notes randomly placed in the speech bubble (cf. Goddin II.43); in terms of precise musical transcription, there is not much to be observed. The 1947 color version of the same panel is more sophisticated (Hergé, Ottokar 28). Although the missing lines and missing links between syllables from the lyrics and particular notes make it hard to ascertain that the second part of the speech bubble is precise in its transcription, at least it could be interpreted as such; the famous upward glissando-type coloratura on "Ah!" is, in any case, clearly sketched out by an upward set of sixteenth notes, in the same manner as in Gounod's musical score. The glissando is also used in the second scene that repeats the same aria (though not in the first one) and-in a manner even closer to Gounod-in one of La Castafiore's later appearances (cf. Hergé, Ottokar 28; Cristal 11). With the upward glissando as a starting point, the partition is recognizable-fittingly for an aria whose lyrics principally touch 
upon recognizability: Margarethe tries on Faust's and Mephistopheles' jewels and rhetorically asks whether it is really still herself that she sees in the mirror now. ${ }^{11}$

The two distinctly referential cases discussed here are untypical both for Hergé's early Tintin albums and for musical notation in comics in general. For the biggest part, Hergé makes recognizable only the lyrics of songs played and sung by his characters. The notes outside of speech bubbles are not immediately linked with these lyrics, and those within can be attributed to particular syllables with a fair deal of goodwill at best. Usually such an association is not possible at all-as is obvious in cases such as the Sur le pont d'Avignon minuet sung by Tintin, a minuet whose famous partition consists exclusively of quarter and eighth notes, but which is here linked to quarter and sixteenth notes alike (Hergé, Étoile 54.12; cf. Famille-Gras n.pag.).

\section{Sounds and Signs in the Asian "Jazz Mecca"}

While the few musical references in the European Tintin scenes were mostly concerned with ridiculing opera, this form of the "culture mélodico-dramatique" considered increasingly outdated by many (Sterckx, Médias 70-71), and while Tintin en Amérique is void of references to American popular culture, including jazz, as well, Tintin's eastwards ventures-the strips that together would eventually become Le Lotus bleu-is a place we have yet to examine. The setting is Shanghai in the 1930s, a city that had a reputation not only for the speed of its traffic and the high number of brothels and opium dens, but also for a highly international and flourishing live music scene, as Steen notes. It was dubbed Asia's "jazz mecca"-analogously to Paris as the European "outpost" for swing and jazz (Steen 145-147). Several of the main sources Hergé used to learn about "the East" helped popularize this view-for instance, the prominently jazzaccompanied 1932 movie Shanghai Express, whose dialogues inspired Hergé's choice of title (cf. Koren 265-269; Mérand/Li 32).

Advertisements, movie theaters, and opium are omnipresent in the album (notwithstanding the looming atmosphere of military conflict), as are Chinese signs and posters protesting Western imperialism (Mérand/Li); yet there are no explicit jazz references here, either. Nevertheless, the album was-as many have argued-the beginning of a new era in the Tintin series. The enhanced attention for detail and cultural nuance in Le Lotus bleu (first version serialized in 1934-1935 and published as a book in 1936) is obvious in several aspects, among them the Mandarin signs that Hergé asked his Chinese friend Zhāng Chōngrén to write for him, and the two main protagonists' famous discussion of cultural stereotyping. Yet this newfound nuance can equally be illustrated with the multiple forms in which sound is noted, transcribed, and evocated. Several different noises stem from cars, trucks, spans of oxen, rickshaws, bicycles, trains, junks, and steamboats. At the same time, none of them are present as onomatopoeia, with the exception of the "TOOO(O)T" of the ship's horn before Tintin's departures $(14.12 ; 62.7 ; 62.10)$. Rather, they are implied in metonymical ways, as synecdoches (cf. Dammann): Characters visibly react to the implied presence of the noises produced by vehicles, which offers playful connections with the text in the speech bubbles. To name but one example: As they supposedly hear and see the Japanese military planes of an air force brigade that is searching for Tintin, Shanghai's pedestrians are turning their heads upwards (41.10) - an action anticipated by the reader, who has seen that the Japanese military official exclaimed "tonnerre!" 
('thunder!') in the previous panel, to emphasize the immediate necessity for these planes to fly.

In terms of the plot of Le Lotus bleu, these airplanes are a threat, as they testify to the imperialist Japanese presence and the consistently hyperbolic asininity and brutality of their military officials. Visually, however, they are a reflection on notation as such. For a Western European audience, the three planes' silhouettes recall the ever-present Traditional Chinese characters in the album-just as the power poles and other silhouettes in the album's many night scenes do (e.g., 55.14; see also FresnaultDeruelle). The silhouettes as an assemblage of strokes: as historically unlikely as this is, it is as if the Lotus album and the most famous Chinese manhua set in Old Shanghai, Zhāng Lèpíng's Sānmáo series (as of 1935), had mutually stimulated each other. ${ }^{12}$

The airplanes' noise is unbearably present for Shanghai's pedestrian population, while the rickshaw apparently only produces negligible sounds. An early scene including this means of transportation illustrates the emphasis Hergé placed on decoding and encoding sounds and visual patterns throughout the album. Tintin's rickshaw runner is here shouting "Mister! Pardon!" in Mandarin, but a white pedestrian, whom we later get to know as the corrupt American industrial businessman Gibbons, does not pay heed (cf. Mérand/Li 20). As a consequence, he causes an accident-and then blames the "chink" for it (Hergé, Lotus 6.7). The noises of this particular strip are implied in the characteristically colorful stars that emanate in panels 6 and 7, stars that equally seem to symbolize the pain for both parties involved in the accident (in panel 6), and the subsequent pain of the rickshaw runner particularly, who has to endure Gibbons' beating (panel 7). The runner's (polite) exclamation in the first panel stands in opposition to the insults and immediate infantilizations uttered by Gibbons; visually, the former's cultural finesse-fine strokes assembled as four characters in a rectangular speech bubble-contrasts the latter's sense of white supremacy-Gibbons holds a newspaper that is presumably implied to be Latin-lettered, but visually only shows blank paper.

21 Le Lotus bleu had a publication history comparable to that of Le Sceptre d'Ottokar discussed above, black-and-white and color versions having been published just briefly before the two versions of the Ottokar album, respectively, and during the golden age of Shanghai's and Brussels' jazz scenes (cf. Steen, Henceval, Danval). Western Europeans at the time had quite a few early texts about the popular craze for ragtime, and later, jazz, at hand. These texts had a common denominator: an acknowledgment of the performative aspect of ragtime and jazz. ${ }^{13}$ In this context, the aforementioned jam sessions in urban environments, with their solos that famously escaped classical notation, "translat[ing] poorly to the printed page" (DeVeaux 82), may have inspired Hergé's experimentation with transcribing and evocating rhythms, tunes, and sounds.

One last example to show how idiosyncratic these transcriptions and evocations are in the Lotus album: As readers of the album's color version, ${ }^{14}$ we are introduced within the first three pages to one of the author's major concerns in the visual narrative, namely, the connection of sounds on the one hand with conventionalized codes (including letters, script, digits, characters) on the other. On page 1, Tintin is tapping out Morse code, with sounds that are first depicted via Latin letters (i.e. onomatopoeia) and then with actual Morse signs (shorts, i.e. dots, and longs, i.e. dashes), and which ultimately result in the reception of a strange (i.e. seemingly incomplete) message-and in noise disturbance for the environment, as Milou complains (Lotus 1.3). The message Tintin 
has received via Morse code is the first of many in the Lotus album that lead him in a particular (geographic) direction, always without absolute certainty whether following the suggestion is a good idea.

Beyond the Morse instruments, Tintin receives an even more explicit hint on these first pages. It is brought to him by a messenger from Shanghai, who attempts to specify Tintin's quest to China, but is cut short by a poisonous dart-the "poison of madness" (cf. Link 4). The messenger's song, only added by Hergé in the color version of the album, is the beginning of a Chinese description of the universe, the four cardinal directions, usually supplemented by the "Middle" ("Zhōng"; cf. Stouff n.pag.). For historical reasons, it is unsurprising that the transcription of these directions is accompanied by four musical notes but not with the four tones we would nowadays expect to see in the Hànyǔ Pinyin transliteration. ${ }^{15}$

Link 4 [fifth line of images from top]:

http://ulislespres.wixsite.com/ulis/copie-de-chap-1-descente-dans-le-te

What we can say, however, is that these two pages form an intermedial reflection on readability of various forms of signs on the page. This becomes more striking in comparison with an older strip. In terms of (Western European conceptions of) politeness, the singsong of the messenger in Le Lotus bleu is the positive counterpart to the torturers that seek to afflict Tintin during his journey in the Pays des Soviets (1930). In the Soviets album, Tintin is supposed to be brutally questioned by Russians, who in turn delegate the particularly foul task of torture to two Chinese characters-as do, incidentally, the American gangsters in the original black-and-white version of Tintin en Amérique (1931-1932). Yet Tintin and Milou outwit them: The Soviet-Chinese are tortured with their own weapons; they singingly utter "unpleasant cries"16, as a result (Link 5).

Link 5 [fourth line of images from top]:

http://ongong.canalblog.com/archives/2013/01/01/25994296.html

The stereotypical nature of the Soviet-Chinese' clothing and hairdo stands in a tradition going back to at least the early nineteenth century. The same is true for the asemic 'Chinese' writing in the speech bubbles, which in turn connects with asemic (or at least non-conventional) musical notes, namely, a hybrid of sixteenth and half notes. ${ }^{17}$ I read this as a reflection on the comics medium. It highlights the fast performance of reception-decoding certain symbolic signs, reducing others to their iconic natureand the liveliness of their production-a type of improvisation originating in highpaced seriality, scarcity of paper, and similar factors. Performativity, improvisation and especially "liveliness," and their use to link comics and jazz, have been a famous discursive trope especially since Gilbert Seldes' essays. As for Hergé, they are typical of his early comics (cf. Sterckx, Médias 25-26; Sutliff Sanders 129-137; Goddin II.142) much more so than of the later works, where the clear line is more firm and less "spontaneous" (Groensteen, "Nez" 35), the material albums less "improvised" (Goddin I.5) and ultimately more prestigious (Gabilliet 258-262). In Hergé's early comics, improvisation seems to stand for a decreased-rather than an increased-sense of control. ${ }^{18}$ 


\section{Dancing without Dancefloors}

$$
\text { so }
$$
particular backgrounds and social settings (cf. Mérand/Li 35; Hergé, Lotus 25). Unsurprisingly, Western-style heterosexual couples' dancing is absent from such a town; kinetic dynamics are only found in fights and chases. Yet the absence of nocturnal dancefloors here connects with the oft-discussed scarcity of romance elements in the overall series (epitomized by the figure of Tintin); it is a constant that connects the early and the late comics by Hergé and his team. It is essential for the comic effect of the many single, or male-male dancing activities in the Tintin series to play out: From the Shanghai messenger in Le Lotus bleu via Tournesol in Rackham le Rouge and Tintin in Tintin au Tibet all the way to Haddock's free-floating three-quarter dance in space in On a marché sur la Lune $e^{21}$, the main characters rather frequently dance when they are intoxicated with either alcohol or the pure ecstasy of some successfully completed action. The characters' temporary lack of control has been written about from various perspectives (e.g., Groensteen, Rire; Sterckx, Schizo). They could easily be connected to the conscious ceding of control that Belgian surrealists adored about early jam sessions. Is not perhaps the aforementioned polysemy of "bœuf" present in Haddock's famous stumbles and ramblings in Les Sept Boules de cristal (11)? Haddock involuntarily holds an artificial oxen's head on his own "roof," and his "dance" eventually leads him back to the music-landing him in the orchestra's bass drum.

It is tempting to continue in this vein: pointing out that the music-hall setting was reflected upon in historical artists' visual depiction of the jazz scene (see Hadler 93-94), or referring to early jazz critics' discussion of the animalistic names chosen for early dancing styles-from "chicken wheel" to "bully dance," from "turkey trot" to "bunny hug," from "bear and hug" to "fox trot." Yet when carried away by such associative chains, we must bear in mind that even enthusiastic and affirmative depictions and writings regularly based themselves on essentialist and primitivist assumptions about race (understood as "nonwhiteness"), as was the case with Gilbert Seldes' earliest writings about the aforementioned liveliness of jazz (cf. Kammen 97-99). As Pim Higginson points out, white jazz critics participated in "producing race" and perpetuating the "racial score" quite prominently in the interwar period, but this practice had much older roots (13-35), and it lived on after WWII (Higginson 4, 41-46). In the postwar context, the Coke en stock album (serial publication 1956-1958) is noteworthy, as it reinforces and simultaneously subverts such essentialisms. Here, the "Africans"-depicted as simple and comparably de-individualized-are puzzled to witness Tintin and his European friends enthusiastically celebrating the fulfillment of 
their plans. As one of the Africans comments, this must, without any doubt, be a performance of the "white men's folk dance" (Coke 57.10). ${ }^{22}$

\section{Speculations about Later Albums}

31 To end this on a speculative note: Might it be the case that Bianca Castafiore is not exclusively based on the physical appearances of opera singer Maria Callas and/or on that of Hergé's friend José De Launoit's mother (cf. Peeters, Lire; Goddin II.43), but additionally on a singer from a blues and jazz context? ${ }^{23}$ Lizzie Miles had gained fame in Paris while living and performing there between 1923 and 1927 (cf. Tucker 320-331). In addition to the fact that her stage name was Rose Noire, or Black Rose ${ }^{24}$ she famously ended her career by giving one more proof of her skills in New Orleans from the audience stand rather than from a stage. This happened and was mediatized in 1959, the time of Hergé's preparation for La Castafiore's most prominent appearance-Les Bijoux de la Castafiore (serial publication 1961-1962). Incidentally, La Castafiore, too, ended up giving her last performance from a place other than a stage (in the Picaros album), and while one could argue for this to be a coincidence, ${ }^{25}$ there are some striking further parallels. Tournesol's gift to the Opera singer, a white rose reflecting her first name (Bianca) ${ }^{26}$ and the "chaste flower" (Casta-fiore), would match Miles' black rose image and her final years in which she shunned all public musical activity, instead living and working as an "old-fashioned nun" in New Orleans (cf. Tucker).

On the surface level, La Castafiore remains a foreseeable character even 13 albums after her first appearance; she is the cliché of classical opera, standing for Gounod and Puccini and, hence, exactly for the type of classical music that Gilbert Seldes famously dismissed on the basis of lacking liveliness (cf. Kammen 105). Yet it is also at the moment of heightened prominence for this most classical of classical performers that more modern forms of music and a more diverse array of folk tunes are hinted at. The Bijoux album is not only full of complex polyrhythms in terms of its panel structure (Molotiu). It also bears a long passage where very minimal scales are "played" up and down and up and down again-in a manner that might bring minimal forms of music of classical and of jazz origin in dialogue with one another. The arpeggios of fingerpicking guitar folk music are one such association-brought forth by cartoonist Jochen Gerner. For Gerner, the scales, ladders, calls and responses in the visual patterns on the page, such as the sequence of chrysanthemum-type flowers blossoming at the foot of Moulinsart castle, thus bring to mind "American Primitive Guitar" musician John Fahey. ${ }^{27}$ Openness for music beyond the classical opera could be read into other passages as well: European modernist composers with an interest in jazz may, with some goodwill, be seen insinuated, as Igor Stravinsky in the first name of La Castafiore's pianist, and Béla Bartók in one of the singer's phonetic mutilation of Haddock's name ("Bartock"). Ultimately, it is a form of folk music-with plucked guitar notes rather than the more continuous sounds of violins (as Molotiu notes)-that appeals to the series' protagonist (Hergé, Bijoux 40).

Thus it may be that Hergé's unease with his own early address and depiction of the Other, of cultural diversity and visually marked alterity, has influenced his allusions to jazz in the Tintin series. In this vein, Hergé's ambivalence is mirrored in Stephen Spielberg's 2011 movie version of his works, or more precisely, in Spielberg's apparent unease with depicting complex non-white personalities (Berlatsky). In any case, in their 
visual innovations as regards depicting sound, tones, and dancing, Hergé's early Tintin comics display a type of nuance far beyond the slapstick clichés he used for the depiction of cultural and racial alterity especially in his earliest albums. Hergé seems to borrow from jazz music's vigor and creative innovation, without, however, turning his full (visual) attention to the richness of jazz culture.

\section{BIBLIOGRAPHY}

Assouline, Pierre. Hergé: The Man Who Created Tintin. Transl. Charles Ruas. Oxford: Oxford UP, 2009. Print.

Blasco-Ibañez, Vicente. Le Voyage d'un romancier autour du monde. Transl. Renée Lafont. Paris: Flammarion, 1928. Print.

Bachmann, Christian A. Macht der Musik: Musik in Karikatur, Bildergeschichte und Comic 1830-1930. Berlin: Christian Bachmann Verlag, 2017. Print.

Beaty, Bart, and Benjamin Woo. The Greatest Comic Book of All Time: Symbolic Capital and the Field of American Comic Books. London: Palgrave, 2016. Print.

Berlatsky, Noah. "How Spielberg Handles the Racial Problems of the 'Tintin' Books." The Atlantic 22 Dec. 2011. Print.

Bettonville, Albert. “Le Jazz et la danse.” America 5 (1947): 64-66. Print.

Blake, Jody. Le Tumulte Noir: Modernist Art and Popular Entertainment in Jazz-Age Paris, 1900-1930. University Park: The Pennsylvania State UP, 1999. Print.

Bremgartner, Mathias. "In the Intermedial Zone: Comic Page Meets Theatre Stage." Conference paper TS (The Mediality and Materiality of Contemporary Comics, Universität Tübingen, April 2015). Print.

Costantini, Alessandro. "Bande dessinée franco-belge, petit-nègre et imaginaire coloniale." Publifarum 14, 1 Nov. 2001. 15 July 2017. Web.

http://publifarum.farum.it/ezine_articles.php?art_id=207

Dammann, Günter. “Temporale Strukturen des Erzählens im Comic.” Ästhetik des Comic. Ed. Michael Hein, Michael Hüners, and Torsten Michaelsen. Berlin: Erich Schmidt Verlag, 2002. 91101. Print.

Danval, Marc. Histoire du jazz en Belgique. Waterloo: Avant-Propos, 2014. Print.

de Moor, Johan. Quick \& Flupke: Haute Tension. Tournai: Casterman, 1985.

DeVeaux, Scott. The Birth of Bebop: A Social and Musical History. Berkeley: U of California P, 1997. Print.

Etter, Lukas. "Transatlantic Comics: Tintin and Superman Crossing the Pond." Handbook of Transatlantic American Studies. Ed. Julia Straub. Berlin, New York: De Gruyter, 2016. 292-309. Print. 
---. “The 'Big Picture' as a Multitude of Fragments: Jason Lutes's Depiction of Weimar Republic Berlin." Transnational Perspectives on Graphic Narratives: Comics at the Crossroads. Ed. Shane Denson, Christina Meyer, and Daniel Stein. London: Bloomsbury, 2013. 229-241. Print.

Famille-Gras. "Tintin et la musique.” 15 July 2017. Web.

http://www.famille-gras.fr/tintin-et-la-musique-solutions-du-quizz

Fresnault-Deruelle, Pierre. Les Mystères du Lotus bleu. Louvain-la-neuve: Éditions Moulinsart, 2006. Print.

Frey, Hugo. "Tintin: The Extreme Right-Wing and the 70th Anniversary Debates." Modern and Contemporary France 7.3 (1999): 361-363. Print.

Fry, Andy. Paris Blues: African American Music and French Popular Culture, 1920-1960. Chicago: U of Chicago P, 2014. Print.

Gabilliet, Jean-Paul. "A Disappointing Crossing: The North American Reception of Asterix and Tintin." Transnational Perspectives on Graphic Narratives: Comics at the Crossroads. Ed. Shane Denson, Christina Meyer, and Daniel Stein. London: Bloomsbury, 2013. 257-270. Print.

Gallois, Christophe, and Tom McCarthy. Jochen Gerner (Monographie). Paris: Éditions B52, 2015. Print.

Glaude, Benoît. “The Experience of Intersemiotic Citation in Blutch's Total Jazz." Image \& Narrative 14.4 (2013): 1-19. Print.

Goddin, Philippe. The Art of Hergé, 1907-1937. Vol. I. Transl. Michael Farr. San Francisco: Last Gasp, 2008. Print.

---. The Art of Hergé, 1937-1949. Vol. II. San Francisco: Last Gasp, 2010. Print.

Groensteen, Thierry. Le Rire de Tintin: Essai sur le comique hergéen. Brussels: Éditions Moulinsart, 2006. Print.

---. “Si le nez de Tintin...” À suivre 42 (1981): 35-36. Print.

Hadler, Mona. "Jazz and the Visual Arts." Arts Magazine 57.10 (1983): 91-102. Print.

[Pseudo] Hergé. “Basin Street à Paris.” America 5 (1947): 70-71. Print.

Hergé. Le Lotus bleu. Tournai: Casterman, 1946. Print.

---. Le Sceptre d'Ottokar. Tournai: Casterman, 1947. Print.

---. Coke en stock. Tournai: Casterman, 1948. Print.

---. Les Bijoux de la Castafiore. Tournai: Casterman, 1963. Print.

---. L'Étoile mystérieuse. Tournai: Casterman, 1966. Print.

---. Tintin au Congo. Tournai: Casterman, 1974. Print.

---. Tintin et les Picaros. Tournai: Casterman, 1976. Print.

---. Les Sept boules de cristal. Tournai: Casterman, 1976. Print.

---. Tintin en noir et blanc. 9 volumes. Tournai: Casterman, 1986. Print.

Henceval, Emile. Dictionnaire du jazz à Bruxelles et en Wallonie. Brussels: Éditions Mardaga, 1991. Print.

Higginson, Pim. Scoring Race: Jazz, Fiction, and Francophone Africa. Martlesham: Boydell \& Brewer, 2017. Print. 
Kammen, Michael. The Lively Arts: Gilbert Seldes and the Transformation of Cultural Criticism in the United States. Oxford: Oxford UP, 1996. Print.

Kannemeyer, Anton. Pappa in Afrika. N.p.: Jacana Media, 2010. Print.

Koren, David. "Shanghai: The Biography of a City." Landscape Biographies: Geographical, Historical and Archeological Perspectives on the Production and Transmission of Landscapes. Ed. Jan Kolen, Johannes Renes, and Rita Hermans. Amsterdam: Amsterdam UP, 2015. 253-282. Print.

Lacour, José André. “Bruxelles-sur-jazz.” À suivre 42 (1981): 37. Print.

Lane, Jeremy F. Jazz and Machine-Age Imperialism: Music, 'Race', and Intellectuals in France, 1918-1945. Ann Arbor: U of Michigan P, 2013. Print.

Lutes, Jason. Berlin: City of Smoke. Montréal: Drawn and Quarterly, 2008. Print.

Maricq, Dominique. “Hergé, Tintin et la musique." Revue des amis du Musée Hergé 6 (2013): 23-24. Print.

Mérand, Patrick, and Ziaohan Li. Le Lotus bleu décrypté. Saint-Maur-des-Fossés: Éditions Sépia, 2009. Print.

Molotiu, Andrei. "The Shape of the Jewel: Polyphony, Polyrhythm, and Musical Structure in The Castafiore Emerald." The Comics of Hergé: When the Lines Are Not so Clear. Ed. Joe Sutliff Sanders. Jackson: UP of Mississippi, 2016. 47-61. Print.

Mouchart, Benoît, and François Rivière. Hergé intime. Nouvelle édition. Paris: Éditions Robert Laffont, 2016. Print.

Newark, Cormac. “Faust, Nested Reception and La Castafiore." Cambridge Opera Journal 25.2 (2013): 165-184. Print.

Parisi, Paolo. Coltrane. Florence: Black Velvet, 2009. Print.

Peeters, Benoît. Hergé, Son of Tintin. Transl. Tina A. Kover. Baltimore: Johns Hopkins UP, 2012. Print.

---. Lire Tintin: Les bijoux ravis. Brussels: Les Impressions Nouvelles, 2007. Print.

Rippl, Gabriele. “Introduction.” Handbook of Intermediality: Literature - Image - Sound - Music. Ed. Rippl. Berlin, New York: De Gruyter, 2015. 1-31. Print.

Sadoul, Numa. Tintin et moi: Entretiens avec Hergé. Tournai: Casterman, 2004. Print.

Screech, Matthew. Masters of the Ninth Art: Bandes Dessinées and Franco-Belgian Identity. Liverpool: Liverpool UP, 2005. Print.

Seldes, Gilbert. 1924. The Seven Lively Arts: The Classic Appraisal of the Popular Arts. New York: Harper \& Brothers, 2001. Print.

Steen, Shannon. Racial Geometries of the Black Atlantic, Asian Pacific and American Theatre. London: Palgrave, 2010. Print.

Stein, Daniel. “Graphic Musical Biography: An Intermedial Case of Musico-Comical Life Writing." Intermediality, Life Writing, and American Studies: Interdisciplinary Perspectives. Ed. Nassim Winnie Balestrini and Ina Bergmann. Berlin: De Gruyter, forthcoming 2018. Print.

Stein, Daniel, and Lukas Etter. "Long-length Serials in the Golden Age of Comic Strips: Production and Reception." The Cambridge History of the Graphic Novel. Ed. Jan Baetens, Hugo Frey, and Stephen Tabachnick. Cambridge: Cambridge UP, forthcoming 2018. Print.

Sterckx, Pierre. Tintin et les médias. Modave: Le Hêtre Pourpre, 1997. Print. 
---. Tintin Schizo. Brussels: Les Impressions Nouvelles, 2007. Print.

Sterckx, Pierre, and André Soupart. Hergé collectionneur d'art. Brussels: Renaissance du Livre, 2006.

Stouff, Jean. "Le Lotus Bleu et les Points Cardinaux.“ Biblioweb, 13 July 2012. 15 July 2017. Web.

https://biblioweb.hypotheses.org/11918

Sutliff Sanders, Joe. "Hergé's Occupations: How the Creator of Tintin Made a Deal with the Devil and Became a Better Cartoonist.” The Comics of Hergé: When the Lines Are Not so Clear. Ed. Sutliff Sanders. Jackson: UP of Mississippi, 2016. 126-140. Print.

Thompson, Harry. Tintin: Hergé and His Creation. London: John Murray, 2011.

Tucker, Sherrie. A Feminist Perspective on New Orleans Jazz Women. New Orleans Jazz National Historical Park. 2004. 22 Aug. 2017. Web.

https://www.nps.gov/jazz/historyculture/upload/New_Orleans_Jazzwomen_RS-2.pdf

Vihlen McGregor, Elizabeth. Jazz and Postwar French Identity: Improvising the Nation. New York: Lexington Books, 2016. Print.

Wilmet, Marcel. Tintin noir sur blanc: L'aventure des aventures. Tournai-Paris: Casterman, 2011. Print.

\section{NOTES}

1. I would like to express my gratitude to the anonymous reviewers as well as Frank Mehring, Erik Redling, and the participants of academic events at the universities of Halle (2016) and Liège (2017) for their valuable feedback on early drafts of this article; further thanks to Regina Ammann, Thomas Coendet, Benoît Glaude, Daniel Stein-and, with particular emphasis, Benoît Crucifix, Christina Maria Koch, and David Pinho Barros.

2. This can at least partly be explained with the Cold War atmosphere that shaped the development of national comics markets (Etter, "Pond"). In my summary of the critical literature about legal restrictions on comics publishing in several countries, a typo is noteworthy: The year of the UK's Children and Young Persons (Harmful Publications) Act is 1955, not 1995 (295). On Hergé's general precursors, see also Stein/Etter; Screech 18.

3. Given the rhetoric of contrast, Sterckx' use of the French term "force" seems to be meant in a positive fashion here-"vigor" or "energy," rather than "coercion."

4. According to Goddin (I.53), Hergé had a habit of bringing a notebook and a pencil even to a dance date with Germaine in Brussels. Among other visual connections to jazz, Goddin also reprints a photo collage Hergé created to accompany a 1928 reportage about jazz in Brussels (I. 44).

5. See Higginson for his discussion of the "jazz shibboleth," a sort of tacit agreement by white critics and fans on the possibility of verbally defining the details of jazz culture, and in such a way that "race-its importance as a central condition for the music's authenticity-plays a central role" (36). Vihlen McGregor (77-124), Lane (35-89), and Higginson (35-47) provide and discuss further literature on these discourses, the latter including a reflection on studying the practices (e.g., musicians' gatherings) of the Western European interwar jazz scenes alongside feuilleton texts.

6. Among the conservative writers dismissing jazz was Georges Duhamel, whose writings about the United States were a major inspiration for Hergé's Tintin en Amérique (cf. Lane 1-3).

7. On the details of the publication history see Wilmet 24-33; among other contextual elements that would warrant further study here are the vicious "coon" images from the late nineteenth 
century, the trope of spirituals or field songs sung during coerced labor, and the discourses on "clowning" and "mugging" in, e.g., Louis Armstrong's performances.

8. Cf. the critical reflection on racist stereotyping going on in Les Bijoux de la Castafiore, where the accusations against the town's Roma people are ultimately revealed as unjustified, and a comparable scene in Hergé's Jo, Zette et Jocko series (cf. Goddin II.44). Albums between Le Lotus bleu and Les Bijoux de la Castafiore often overtly address social injustice, yet as so many other comics they do so through the use of stereotypical notions of marked Otherness-cf. the Coke en stock example discussed further down.

9. Cf. Costantini n.pag., n.37. The song is still frequently sung today by Belgian children. I am indebted to the members of a discussion in the ACME Speaker series at Université de Liège (Nov. 2017) for this information, and further useful hints.

10. Costantini names other comics with similar connections. The personified musical notes in Johan de Moor's Quick \& Flupke album Haute Tension, 12-13, could also be studied in this context.

11. Cf. Newark 173-180. Another somewhat concrete set of notes is found in Hergé, Lotus 23.16. Benoît Glaude deserves credit for pointing out Newark's text to me.

12. This is particularly evident for the black-and-white versions of Sanmao, this impoverished boy's adventures. Lèpíng's clear line of the character outlines, ornaments, and medium conventions such as speed lines, often seem to be deliberately causing friction with the strokes of the few verbal elements in this otherwise pantomimic comic strip (e.g., pages 9, 116-117, 182-183 in Sānmáo liúlàng ji). Its depiction of Shanghai's poverty serves as a stark contrast to the city's world of entertainment. To reiterate the introductory paragraphs, it would necessitate further in-depth studies to do justice to such connections.

13. Innumerable critics and writers have focused on this aspect, in the 1910s (e.g., Ernest Ansermet) just as much as in the 1940s (e.g., Albert Bettonville), and beyond (cf. also Blake 121). When listing these texts, one would have to add a two-page essay published in 1947 and signed under "Hergé" (cf. [Pseudo] Hergé)-most likely, a pun by Hergé's contemporary and countryman Robert Goffin, whose initials match the (inverted) ones of "Georges Rémi" (cf. Maricq). For literature on the racial essentialism that routinely shaped such writings, see the secondary literature listed in earlier notes; for a discussion of Ansermet's critical afterlife in the Journal de Tintin, see Fry 200-232.

14. The publication history of this album is again rather complex (cf. Wilmet 60-73), but for our purposes it can be summarized that the pages in question have been substantially redone and extended in the color version of the album, published in 1946.

15. As Stouff notes, Hergé and his team used the official system of transcription of the time, that of the École Française d'Extrême-Orient (n.pag.). It would be tempting to push further the notion of tones in this example, claiming that the three tones used in the Pīnyīn Romanization (Dōng, East; Xī, West; Nán, South; Běi, North) are associated with the three types of length of musical notes. Yet this would remain speculative, as the clearly different pitch levels of the first and second pair of eighth notes would yet have to be addressed.

16. This is the sarcastic comment made by Tintin (Soviets 71.5; my translation).

17. Irrespective of whether this was inspired by the plants in Burnand's illustration, similarly asemic 'musical notation' can be found in the same album (Soviets 121) and later in the series (e.g., Ottokar 29; Picaros 33; Cristal 11). The early albums almost consistently diverge from standard musical notation in the places where musical notes with downward-directed stems are used. Livio Russi deserves credit for this observation.

18. To name just one example: A sample page Hergé and E. P. Jacobs prepared in order to start genre fiction under a pseudonym ("Olav") towards the end of 1944 showed a white man being assaulted by a Chinese criminal (again, in clichéd traditional garb) in nocturnal Shanghai. Having 
evidently no access to the expertise of their Chinese friend at this time, Hergé and Jacobs relied on the same background advertisement Zhāng had prepared for Lotus bleu. Yet the strokes that are supposed to read "Siemens" next to a drawn light bulb, i.e., this copy of the tonal transliteration of "Siemens" into Chinese syllables, resulted in asemic writing, incidentally resembling a violin clef more so than a Chinese character. The sample page (along with two others, equally genre fiction) has not been bought by a publisher, nor has it ever been expanded. Biographer Goddin notes that the production atmosphere was one of hectic and insecurity (Goddin II.142); nevertheless, it is a crucial episode that debunks the myth of a monolithically working auteur that Hergé was often mediatized as in the postwar period.

19. On the expression "boitte de nuit" and its use in the 1920s, cf., for instance, the entry in the CNRTL's dictionary; on "zero-perspective" cf. Etter, "Fragments" 234-236.

20. Interestingly, one of the sources consulted by Hergé, Blasco-Ibañez' description of China (cf. Mérand/Li 62), describes Shanghai's "café-chantants" as part of its "boom" phase and then adds a critical reflection on the onomatopoetic nature of this English term (154-155).

21. The three-quarter rhythm, although not explicated on the comics page, is at the basis of the marine song "Goodbye Farewell" that Haddock sings in a state of severe inebriation.

22. In the original French: "[la] danse folklorique des hommes blancs" (57.10). The depictions of "Africans" in Coke en stock has stirred debates; their way of talking has been altered in later editions (cf. Costantini). On such controversies more generally cf. Frey.

23. Such a transfer seems to be implicitly suggested in Blutch's Castafiore pastiche; cf. Glaude.

24. In the 1950s, there was an important Brussels-based jazz club with the same name (cf. Danval 162-171).

25. Judging from the sketches of the unfinished Tintin et l'Alph-Art, La Castafiore was going to have a prominent appearance there, too.

26. How the expressions "black" and "white" may retain specific colonially or postcolonially defined associations, is a prominent topic of younger artists iconographically connected to Hergé's albums. Artists like Anton Kannemeyer follow Hergé's ligne claire style but use it for new, often radically anti-imperialist and deliberately iconoclastic images (cf. Kannemeyer n.pag.).

27. Gallois/McCarthy 17. Benoît Crucifix contributed this reference.

\section{ABSTRACTS}

"Jazzy" or not, the close intermedial encounter of jazz and comics, i.e., two medially and semiotically complex forms of expression already by themselves, asks for a general reflection on the nature of sound in combination with visual notes, scores, movement, and performance in the comics medium. The present essay illuminates how such encounters take shape in specific Francophone Belgian comics of the 1920s and 1930s; it consists of a close reading of musical and sound notation in Hergé's early Aventures de Tintin albums. It departs from the observation that somebody like Hergé, with an oft-reported affinity for jazz, would shy away from making allusion to thriving dancefloors and the presence of African American musicians so central in the "white" Western European discourses of these decades. The essay sheds light on whether this is closely linked to or, conversely, contrasted from colonialist attitudes Hergé propagates especially in his earliest albums-and on how allusions to the jazz age and American music may be read between the panel lines in some Tintin albums all the same. 
INDEX

Keywords: comics, interwar Europe, intermediality, jazz, musical notation, racism, Tintin

\section{AUTHOR}

\section{LUKAS ETTER}

Lukas Etter is a scholar of American Studies at the Seminar für Anglistik of the University of Siegen, Germany. In 2014, he defended his doctoral dissertation Auteurgraphy: Distinctiveness of Styles in Alternative Graphic Narratives at the University of Bern. His research interests include several aspects of comics studies (especially visual style) and the discourses on mathematics education in $19^{\text {th }}$-century literature and culture. Recent and forthcoming publications include (with Daniel Stein) "Long-length Serials in the Golden Age of Comic Strips: Production and Reception" in The Cambridge History of the Graphic Novel (ed. Baetens/Frey/Tabachnick, forthcoming 2018), and "Visible Hand? Subjectivity and Its Stylistic Markers in Graphic Narratives" in Subjectivity across Media: Interdisciplinary and Transmedial Perspectives (ed. Reinerth/ Thon, 2017). 